\title{
A Study on the Correlation between Motivation and Students' Speaking Performance at an Indonesian Vocational High school Context
}

\author{
Ratnawati \\ ratnawati.aba@umi.ac.id \\ Sumirna \\ sumirna.aba@umi.ac.id \\ Hikma Nurul Isma \\ Isma212@gmail.com
}

Akademi Bahasa Asing UMI

\begin{abstract}
This study aims to find out vocational high school students' speaking performance in correlation with their motivation for learning English. This study employs a quantitative research method using a questionnaire to gather the data. The whole population in this study was the first grade of SMK Negeri 6 Makassar, which consists of three classes numbering 86 students. The samples were students from class b, which consists of 25 students. The sample was taken by using purposive sampling technique. This study was conducted by distributing questionnaires to students who were respondents and test, after which they were input and analyzed through the SPSS program. The findings revealed that the correlation between motivation and speaking performance for vocational high school students indicated that it was strong enough or categorized as medium correlation. Furthermore, the findings showed that motivated students usually feel more comfortable in their learning, providing the students to speak up confidently wherever they are even although English is considered as a foreign language.
\end{abstract}

Keywords : Correlation, Motivation, Speaking Performance.

\section{INTRODUCTION}

English is known as a second or foreign language that is learned by people in the world. This is because English was claimed as an International language and demanded people to learn this language. Then, English is not only learned by people for business and other purposes, but also by the students in all stages of school. In Indonesian formal education, English has been taught and learned from primary school up to university. The four language skills are then used as a measurement of language comprehension. One of the examples is speaking skill. Speaking is one of the skills that can be used in communication widely; in speaking, especially give more information for people, it makes a more natural way to learn English 
spontaneously. Moreover, speaking is essential to be mastered by people if they want to get many pieces of information. Emphasizes that speaking skill is a skill in producing an oral language. Speaking has some variable connections, such as selfconfidence, vocabulary, and motivation. One of the examples is motivation behavior (Sidik,2013,p.3).

Speaking is a complex skill among the other three skills in English. No doubt that many students get difficulties in leaming speaking, moreover to practice it. To learn speaking skill is not only learning about the language itself but also learning how to speak in real con cannot use English in the classroom and in real communication. Because English is not their mother tongue, it is rarely used in daily activities to interact with others. They are accustomed to using English neither in the classroom nor outside the classroom. On the other hand, actually, to get success in learning to speak, students should be at the situation in which they are willing to speak in English. Besides, students also should have the strength inside to speak up. In other words, many factors affect students in learning speaking (Istianti, 2013).

Research about motivation had been conducted by Safari and Fitriati (2016.p,4) they investigated the learning strategies that the learners used with different speaking performance, one of their finding was stated that learners with high speaking performance seemed to have a higher motivation than low speaking performance. That research also supports the research that comes from Fitriati \& Trisanti (2017.p,5), which explored more variables of individual differences such as classroom climates, learning discipline, and learning motivation. They found that learning motivation is the most dominant in affecting learning outcomes.

Motivation becomes a way that exists when someone has some desires to reach some goals in his/her life. The goal will motivate him/her to reach it. Motivation exists in our minds and influences our bodies to move and act in order to reach our goals. In addition, motivation to learn is the adoption of learning goals and related strategies, and it is not linked directly to either extrinsic motivation or intrinsic motivation. Motivation can give positive influence and effect for the students to make them feel enjoy to improve their vocal performance. Based on the explanation above, the researcher is interested in conducting research entitled "The Correlation Between Motivation and Students Speaking Performance at SMKN 6 Makassar". The writer formulates the following questions; (1) what is the students' motivation in regards to learning English? (2) How is the students' speaking performance in English? And (3) what is the correlation between students' motivation in learning English and students' speaking performance?

\section{LITERATURE OF REVIEW}

Self-esteem and confidence are crucial factors influencing motivation and that the self-esteem of learners is influenced by feedback from teachers. Teachers consider evaluative and strategic feedback carefully and try to communicate a sense of optimism, so learners can-do attitudes and various strategies for teachers to maintain motivation. First, teachers should experiment and different classroom activities to see which activities individuals do best. They should also choose tasks that give learners the chance to make decisions about what to do. Furthermore, 
choosing open-ended tasks with a range of possible responses and providing choice for learners to decide what to do ( Putra,2017,p.47).

Based on definitions of motivation above, the writer get the conclusion motivation as something happens within an individual which makes he or she do an action to achieve his or her goal. So, the writer infers motivation in learning as the drive to push the teacher and the learner to do learning activities in order to achieve learning goals. Hierarchy of human arranged in the following order of priority: Physiological needs, it means students need sleep and thirst; safety needs, students needs psychological threat; love needs, students need love from parents, teachers and environment; esteem needs, students need confidence in one's performance; and needs for self-actualization, students will be creative to explore self-expression. There are some characteristics of motivated learners: positive task orientation, ego involvement, need for achievement, high aspirations, goal orientation, perseverance and tolerance of ambiguity (Bropy, 2010,p.22).

The critical role of motivation in learning process is that motivation can determine whether the learning process issuccessful or failed. It means that the motivated learner will get a better opportunity to succeed in their learning activities than who have low motivation. Because,motivation is essential part/ factor in teaching and learning process which can influences and make the student do activities in learning process successfully (Putra,2017,p.50) It is a useful reminder that in order can help to motivate students successfully and effectively motivation in every condition. And motivate behavior is necessary give in the classroom and learning process, especially in speaking learning process in every meet in the classroom, include some dimension; positif task orientation, ego involvement, need for achievement, high aspirations, goal orientation, perseverance and tolerance of ambiguity

\section{METHOD}

Research method used a quantitative approach. Data obtained from the questionnaire using inferential statistics. This research used correlation. Correlation analysis is used to determine whether there is a relationship between variables $\mathrm{X}$ (motivation) as the dependent variable and the variable Y (speaking performance ) as the independent variable. Moreover, regression analysis used in this study, which is based on a simple regression analysis of the functional or causal relationship an independent variable in the dependent variable (Sugiyono, 2011).

The population of the study is the first grade of SMK Negeri 6 Makassar. They consist of three classes. The total were 86 population. The sample of the study one class that is $\mathrm{X}$ boga 2 which had 25 student. The sample is taken by using purposive sampling technique, the determining of class that has studied based on the policy and ease from the university.

In this research, to find answers to the research questions, the researcher used several procedures has used in order to get the empirical data required. the writer will use three technique, they are quistionnaire, test and documentation. To get data of students' motivation in learning speaking, the writer questionnaires to get students' answers. Motivation test are consisted of a number of questions should be 
answered by respondents asking about their actions and beliefs. The motivation test consists of many items involving attitude and motivation but the authors only took 30 items which are suitable with this study. Therefore, the authors only took motivation statements from AMTB and then translated into Indonesian language. Motivation Test are "closed", it means the respondents are only choosing the best one on the items and making checklist on the given answers. To test the students' speaking skill the researcher was used performance test, the test was to measure the students skill in speaking, than the test was distributed to the students' by giving them a topic and ask them to speak in front of others about everything they know based on the topic.

In finding the students' scoring of motivation and student's vocal performance was analyzed using SPSS program, the researcher has used, the formula to analyze the data:

Note:

$$
\mathrm{P}=\frac{\mathrm{n}}{\sum N} \times 100 \%
$$

$$
\begin{aligned}
& \mathrm{P}=\text { percentage } \\
& \mathrm{n}=\text { number of type or reason } \\
& \mathrm{N}=\text { total number of data }
\end{aligned}
$$

\section{RESULT AND DISCUSSIONS}

This study was conducted in SMKN 6 makassar at X grade in the academic year of 2018- 2019. SMKN 6 Makassar is one of senior high schools in Makassar. It place at Andi Djemma Street Makassar city. This study was conducted in order to find out the correation between students motivation and their speaking performance. The researcher analyzed the data using SPSS.

\section{A. Students' Motivation}

In this study students' motivation in learning speaking is as independent variabel (X). The following table describes the result of students' motivation in learning speaking after accumulated.

Table 4.1

Score of Students' Motivation in Learning English

\begin{tabular}{|c|c|}
\hline Students' (N) & Motivation (X) \\
\hline 1 & 91 \\
\hline 2 & 85 \\
\hline 3 & 85 \\
\hline 4 & 79 \\
\hline 5 & 87 \\
\hline 6 & 86 \\
\hline 7 & 80 \\
\hline 8 & 89 \\
\hline 9 & 80 \\
\hline 10 & 67 \\
\hline 11 & 83 \\
\hline
\end{tabular}


ELT Worldwide Vol. 6 No. 2 (2019) Ratnawati, Sumirna, Isma : A Study on the Correlation Between ...

\begin{tabular}{|c|c|}
\hline 12 & 79 \\
\hline 13 & 78 \\
\hline Students' (N) & Motivation $\mathbf{( X )}$ \\
\hline 14 & 81 \\
\hline 15 & 87 \\
\hline 16 & 85 \\
\hline 17 & 80 \\
\hline 18 & 87 \\
\hline 19 & 80 \\
\hline 20 & 80 \\
\hline 21 & 80 \\
\hline 22 & 75 \\
\hline 23 & 86 \\
\hline 24 & 85 \\
\hline 25 & $\mathbf{7 6}$ \\
\hline $\mathbf{N = 2 5}$ & $\mathbf{X = 2 0 5 1}$ \\
\hline
\end{tabular}

The table 4.1 showed above the total score of 25 students' is 2051 , Here are the the total score motivation in English as accumulation score from raters:

Table 4.2

The Percentage of motivation in English

\begin{tabular}{|c|c|c|}
\hline Interval motivation & $\mathbf{n}$ & \% \\
\hline Higest (91-83) & 12 & $48 \%$ \\
\hline Average (82-75) & 12 & $48 \%$ \\
\hline Lowest (74-67) & 1 & $4 \%$ \\
\hline Total & $\mathbf{2 5}$ & $\mathbf{1 0 0 \%}$ \\
\hline
\end{tabular}

The table 4.2 showed above that the data of interval motivation in learning English. From 25 students', there were 12 students' who got 91-83 (48\%), its means that their motivation in learning English were highest. There were 12 students' who got 82-75 (48\%), its means that their motivation in learning in English were Average. 1 student who got 74-67 (4\%), its mean that their motivation in lerning English were lowest.

\section{B. Students' Speaking Perfomance}

In this study students' performance is as the dependent variable (Y). To know students' speaking score, the researcher conducted oral test to the students'. Here are the result students' speaking performance.

Table 4.3

Score of Students' Speaking Performance

\begin{tabular}{|c|c|}
\hline Students & Speaking (Y) \\
\hline 1 & 85 \\
\hline 2 & 85 \\
\hline 3 & 85 \\
\hline 4 & 80 \\
\hline 5 & 80 \\
\hline 6 & 80 \\
\hline 7 & 75 \\
\hline
\end{tabular}




\begin{tabular}{|c|c|}
\hline 8 & 80 \\
\hline 9 & 80 \\
\hline 10 & 80 \\
\hline 11 & 80 \\
\hline 12 & 80 \\
\hline 13 & 75 \\
\hline 14 & 70 \\
\hline 15 & 70 \\
\hline 16 & 70 \\
\hline 17 & 70 \\
\hline 18 & 75 \\
\hline 19 & 75 \\
\hline 21 & 70 \\
\hline 22 & 65 \\
\hline 23 & 70 \\
\hline 24 & 70 \\
\hline 25 & 50 \\
\hline $\mathbf{N = 2 5}$ & 65 \\
\hline & $\mathbf{Y = 1 8 6 5}$ \\
\hline
\end{tabular}

The table 4.3 showed above the total score of 25 students' is 1865 , Here are the the total score speaking performance in English as accumulation score from raters:

Table 4.4

The Percentage of Speaking Performance in English

\begin{tabular}{|c|c|c|}
\hline Interval score speaking & $\mathbf{n}$ & $\mathbf{\%}$ \\
\hline Higest (85-73) & 15 & $60 \%$ \\
\hline Average (72-61) & 9 & $36 \%$ \\
\hline Lowest (76-50) & 1 & $4 \%$ \\
\hline Total & $\mathbf{2 5}$ & $\mathbf{1 0 0 \%}$ \\
\hline
\end{tabular}

The table 4.4 showed above that the data of interval score speaking performance. From 25 students', there were 15 students' who got 85-73 (60\%), its means that their vocal performance were highest. There were 9 students' who got 72-61 (36\%), its means that their speaking motivation were Average. 1 student who got 76-50 (4\%), its mean that their speaking performance were lowest.

C. The correlation between students' motivation learning English and students' speaking performance

In this study, both of students' motivation and speaking performance are correlated by using SPSS. The following the computation result of the two variables.

Table 4.5

Correlation motivation and students' speaking performance

\begin{tabular}{|l|l|l|l|}
\hline \multicolumn{1}{|c|}{ correlation } & \multicolumn{1}{c|}{ motivation } & Speaking perfomance & Pvalue \\
\hline Motivation & 1 & 0.821 & 0.01 \\
\hline Speaking perfomance & 0.821 & 1 & \\
\hline
\end{tabular}


From the table 4.5 showed above that of statistical tests used Chi-square test between variables obtained value $\mathrm{p}=0.01$, its means that there is correlation between students' motivation (X variable) and speaking performance ( $\mathrm{Y}$ variable) at SMKN 9 Makassar.

\section{Discussion}

The purpose of this research was to find out the correlation between students' motivation and students' speaking performance. From the finding above, the researcher concluded that there was a positive correlation between students' motivation and their speaking performance in SMKN 6 Makassar. It can be concluded that there is a significant correlation between students' motivation in learning English (x variable) and speaking performance ( $\mathrm{Y}$ variable).

After analyzing both variables by SPSS program, it is found that lsy 0.821 . Based on the result of lxy 0.821 . It is considered that there is medium correlation between students' motivation in learning English and students' speaking performance. Bisides, by looking at calculation above, there is positive correlation between $\mathrm{X}$ variable and $\mathrm{Y}$ variable. Its means that students with higher motivation will get better speaking performance than the lowe one. In other words, the more motivated student are, the better speaking performance can be achieved.

a. Student' motivation learning English

Table 4.1 the showed that the total score motivation in English of 25 students' is 2051. By applying SPSS Program, it shows that the minimum score of students' motivation was 67 , the maximum score of students' motivation score was 91 , the mean of students' motivation score was 82.04 , and the range was 24 . The result of classroom observation also confirms its shows that students who have high motivation score also follow that teaching and learning process well, pay attention to the teacher's explanation, express the ideas, do assighment from teacher.

According to table 4.2 about motivation sudents' in learning English, Based on the statistic result above, there are 3 interval score of motivation. Average, minimum and maximum, there were 12 students' were highest motivation. There were 12 students' were Average motivation. 1 student were lowest motivation.

b. Students' speaking performance in English

Table 4.3 Table 4.1 the showed that the total score speaking performance in English of 25 students' is 1865 . By applying SPSS Program, the minimum score of students' speaking performance was 50, the maximum score of students' speaking score is 85 , the mean score was 74.60 , and the range was 35 .

Table 4.4 the showed the result students' speaking performance that the data of interval score speaking performance. From 25 students', there were 15 that their speaking performance were highest. There were 9 students' that their speaking motivation were Average. 1 student that their speaking performance were lowest.

The test is used to compare students achievements before conducting the research and after conducting the research. The writer conducted an oral test, type of speaking tests in the form of monologue text. The test carried out to measure how far students can improve their vocal performance through motivation. Furthermore, to know the validity of the test, the researcher used content validity.

The reasercher Erviana (2016) and Kamaludin (2013). On the other hand, students with low interest performed speaking poorly, in some cases they read the notes that they brought. Automatically, it influenced their fluency, pronunciation, mimics, and overall performance. Because speaking performance is in form of Role 
Play, student need to be taught the way how to implement the portrayal of good role play, Insani (2014).

c. Correlation between motivation and students' speaking performance

From the calculation table 4.5, the researcher found that the coefficient correlation between students' motivation in English and their speaking performance was 0.821 at significance level of 0.01 . It means that the correlation between students' motivation and their speaking performance was strong. This data answered the hypothesis testing of this research, which was showed that there is correlation between both of variables. For the contribution of motivation toward students' English speaking performance, the Simple Regression analysis was used to see how far the contribution of students' motivation contributes their English speaking performance.

Based on the data of the result, students showed how motivation took place on their activities. Motivation had an important role in language learning process. Motivation was like an organizer on their self which aroused their desire to learn. Students who were motivated were more successful than students who were not motivated. However, some of the students who were not motivated they were able to practice their performance in speaking. Students who were motivated needed to force themselves to practice and made themselves had a positive habitual to speak in English. Motivation drove the students to pay more attention to the subject.

Motivation made the students ready in teaching learning process. So, the students understood easily about the material in learning speaking. Students who were motivated had practice their performance on their spare time. It was because an enjoy feeling on their self so they were happy in doing this activity. The students who were motivated were successfull in speaking achievement. Because they paid attention to the materials. The students also paid attention to how the teacher practiced the word. When the teacher gave the example of word, they paid attention to the written word. When they found the difficulties, they asked their teacher to repeat the utterances.

The students who were motivated were aware about the aim of learning process in the class. They were aware that they should reach the goal of the process to get the achievement. This awareness created desire to learn moreover to practice the performance. The students who were motivated would be helpfull in acquiring new information and decrease the effect of low motivation. In addition, it was also evident that the students who were motivated, the more they were able to benefit from they learning activities.

Lightbrown and Spada (2001) identify motivation as an intricate incident which can be identified along with two factors: "learners' communicative and their attitudes towards the second language community". They believed that when learners thought that they needed to speak the second language to be in touch with others or accomplish and achieving specialized desires and goals. They were motivated to obtain expertise and skill in it.

Related to motivation questionnaire, students showed how much motivation contributes their self. Students who had motivation were success in speaking. Most language educators probably believed that motivation caused better acquisition although there was some evidence that moderate or low motivation can be just as strong. (Gardner and MacIntyre 1992). It was caused why students can success in speaking test. The students who were highly motivated paid more attention so they understood faster than other students. They were listened and read the written word carefully. They concerned in the way of how the speaker pronounced the word. By 
their motivation, they learned to speak seriously. As Krashen (1981) claims that with high motivation, self-confidence, good self-esteem, and low-level anxiety, a student will be better for success in second language acquisition.

Low motivation, low self-confidence, and low self-esteem and debilitating anxiety formed a mental block that prevents comprehensible input for language acquisition. When the students had good motivation, they had more inner state of need or desire that actives an individual to do something to satisfy them. Motivation became the forces that account for the arousal, selection, direction, and continuation of behavior. Motivation drove an individual to take a positive effect on their life.

There are internal factors related to learners' aspects of motivation. There are goals set, expectancy, anxiety, self-confidence, and self-efficacy. In students' perspectives, goals setting and expectancy were the most prominent factors in sustaining their motivation to learn English. Most students had set goals for their English learning and had high expectation of the goal-attainment. Although these two aspects did not rank the most prominent place in the result of teachers' questionnaires, most teachers still confirmed the great effects of them.

Unexpectedly, students' questionnaire did not show the very high anxiety in English class as teachers' perceived. Self-confidence and self-efficacy were not salient in the students' part. It appeared that students were lacking self-confidence and with a low sense of self-efficacy in general, which to a large extent, made them underpowered to sustain the effort in English learning, especially when facing obstacles or failures.

\section{CONCLUSIONS, IMPLICATION, AND SUGGESTIONS}

The research aimed to find out the correlation between students' motivation and students' speaking skills. Therefore, the hypothesis was that there is a significant correlation between students' motivation as X variable and students' speaking skills as $\mathrm{Y}$ variable. It was proved by testing the correlation between both of them. The result of this correlation indicated that the correlation between students' motivation and students' speaking skill was strong enough or medium correlation.

The hypothesis of correlation between students' motivation and student's speaking performance has been proved. It means that the researcher agree to some experts of motivation about the theory of motivation. Some experts of motivation said that motivation is one of the successful factors that influence students in speaking performance. In other words, if the motivation is higher, the students speaking performance will be better.

The students who are learning to speak, will be able to achieve the better speaking performance by using motivation. The students who have high motivation will make an effort to follow the learning process intensively, and they learn the lesson as well as possible not only in the school but also outside the school. They were motivated to enrich their vocabulary and to practice their speaking performance. Moreover, motivated students usually feel enjoy in their learning. It makes them easier to speak up confidently wherever they are although English is a foreign language. 
Based on the problems of the research, the researcher gives the suggestions to the teacher and the further researchers as follows;

1. The teacher should create an interesting and comfortable situation in the classroom in order to make students speak up confidently. Besides, students should also have motivation from inside themselves to learn to speak. It can encourage students to learn and to achieve their goals. The teacher should improve the students' motivation in learning English, especially in speaking skills, because motivated students will concentrate and enjoy the teaching and learning process.

2. For further researchers who are interested in conducting a similar study, this study can be used as a reference for them to support their study. It is also suggested that other researchers are expected to take the larger sample in their study because the sample of this study is only 25 respondents. They are also suggested to conduct their study in a long time in order to get more valid and more reliable data.

\section{REFERENCES}

Arham, M., Akrab, A.H. (2018). Delving into Content Lecturers' Teaching Capability in Content Language Integrated Learning (CLIL) at an Indonesian University, Asian ESP Journal, Vol. 14 No. 7.2 (2018).

Anthony,Govindarajan.2005.Management Control System. Edisi Pertama , Penerbit Salemba Empat,Jakarta

Brophy. 2010. Motivating Students to Learn. Third Edition. New York: Routlege.

Brown, H.2008. Prinsip Pembelajaran dan Pengajaran Bahasa. Amerika Serikat: Pearson Education, Inc.

Chandler, Richardson, Scott. 2007. 100 ways to Motivate Others. Jakarta: PT Bhuana Ilmu Populer.

Dale H. Schunk. 2012. Learning Theories An Educational Perspective. Boston

Douglas,Brown.2004. Teaching by Principes an Interactive Approach to Laguage Pedagogy. Logman

Fitriati, Isfara, Trisanti. 2017. Teachers Questioning Strategies To Elicit Students Verbal Responses In EFL Classes At A Secondary School

Gamidge,David T.2004.Decentralisation And School-Based Management In Thailand

Harmer. 2007. The Practice of English Language Teaching. Fourth Edition. England: Pearson Education Limited

Istianti, Nerfi. 2013. The Correlation Between Students Motivation In Lerning Speaking And Their Speaking Ability. University Jakarta

Marsh, Colin. 2010. Becoming A Teacher Knowledge, Skills And Issues.New South Wales: pearson Australia

Masnaini. 2009. An analysis on students Ability Speaking By Using Peers Tutorial Teaching Strategy. Gorontalo. Letters and Culture Faculty.

Milchatun, Bharati, Hartono. 2015. Improving Students' Personal Self Concept Through Role Play Technique in Teaching Speaking Skill.

Nation,Newton.2009. Teaching ESL/EFL Listening and speaking. New York and London: Routledge

Pakdel, Behnaz. 2013. The Historical Context of Motivation and Analysis Theories Individual Motivation. London: Baku State University

Putra, Aidil S. 2017. The Correlation Between Motivation And Speaking Ability. Muhammadiyah University of Tangerang

Safari, Fitriati. 2016. Learning Strategies Used by Learners with Different Speaking Performance for Developing Speaking Ability. 
Sidik, A. 2013. Improving Students' Speaking Ability Through Practice Rehearsal Pair of The Tenth Grade of Man Malang 1.

Sugiyono. 2011. Metode Penelitian Kuantitatif, Kualitatif dan $R \&$ D. Bandung: Alfabeta. Syakir, A. 2009. The Correlation Between Self-Concept And English Speaking Ability Of Learner Of Primagama English Course Samarinda. 